\title{
THE ARRANGEMENT OF MODERN RETAIL INDUSTRY IN THE PERSPECTIVE OF POSITIVE LAW IN INDONESIA
}

\author{
By :
}

Sandra Megayanti, Candra Irawan, Emelia Kontesa

\begin{abstract}
Indonesia is a state law that all aspects of life in the areas of society, nationality and state affairs including government affairs should be based on the law in accordance with the national legal system, not least in terms of the economy. Economy is the backbone of public welfare, while the law plays an important role that determines how the prosperity achieved and felt by the people. One of the industries that participate in contributing to the growth and development of the Indonesian economy is the modern retail industry. The existence of the modern retail industry as having two sides of a coin, which on the one hand its existence becomes an important part in the economy, one of them in terms of employment. However, on the other hand, the existence of the modern retail industry raises problems, one of which is the rise of this industry makes the small and medium businesses cannot compete. Nevertheless, the existence of modern retail is currently being faced with adverse situations, where there are a lot of modern retailers who had to close their shops in a number of places, in addition, the proliferation of online businesses also adds problems in the modern retail industry. This study aimed to analyze the arrangement of modern retail industry in the perspective of Indonesian positive law. In this case, researcher used a normative legal research methods with qualitative juridical analysis. In terms of setting, the existence of the modern retail industry has not been able to provide its effectiveness in achieving fairness, certainty and expediency. Currently, the setting of modern retail industry could be seen in some rules, such as Law No. 7 of 2014 About the Trade, Law No. 5 of 1999 concerning Prohibition of Monopolistic Practices and Unfair Competition, Law No. 25 of 2007 on Investment, President Regulation No. 112 of 2007 on Planning and Development of Traditional Markets, Shopping Centers and Modern Stores, and Government Regulation No. 44 of 1997 concerning the Partnership. However, the implementation of these regulations have not been going well because there is no consistency in the process of administration of justice, both by governments and businessesactors.
\end{abstract}

Keywords: State of Law, Modern Retail, Positive Law in Indonesia 


\section{A. INTRODUCTION}

\section{Background of the Study}

The Republic of Indonesia as a state of law ${ }^{1}$, The formula gives the sense that the highest authority in the State of Indonesia is the law, and as the State of law all aspects of life in the areas of society, nationality and state affairs including government affairs should be based on the law in accordance with the national legal system, not least in terms of the economy. Economics is the backbone of public welfare, while science and technology are the reinforcing pillars of progress of a nation, but there is no denying that the law is a regulation that ultimately determines how the social prosperity can be enjoyed equitably, how social justice can be achieved and how science and technology can bring happiness to the masses $^{2}$.

The provisions of Article 33 of the Constitution of the Republic of Indonesia Year 1945 is the basic guideline for the underlying laws

${ }^{1}$ Provisions of Article 1 Paragraph (3) of the 1945 Constitution of the Republic of Indonesia, State Gazette of the Republic of Indonesia of 2006 Number 14

${ }^{2}$ Candra Irawan, Dasar-Dasar Pemikiran Hukum Ekonomi Indonesia, CV.Mandar Maju, Bandung, 2012, p.9 governing the economic activities in Indonesia. However, in practice, there are many laws that ignore it, besides, there is a contradiction between the legislation with each other. The condition occurs in the arrangement of the modern retail industry.Speaking further about the modern retail industry, on one side of existence has become an important part of the economy, especially in terms of employment and economic growth itself. Data compiled by the Central Statistics Agency (BPS) in 2017 showed that retail is able to absorb 28.17 million labor force. However, on the other side, the existence of the modern retail industry raises several issues, including the rise of the modern retail industry make the actors of small and medium enterprises "loss in competition" so they cannot develop their business. In addition, the arrangement of the existence of the modern retail industry is considered as unable to give its effectiveness becomes an important issue that needs to be resolved shortly. Other issues currently being faced by the modern retail industry is the decline in trading activity of modern retail industry 
which of those resulted in some companies had to close down their business. The closing of a number of retail outlets, one of which is caused by the proliferation of online business activities which currently attracts a lot of consumer interest. Based on the above description, the writer was interested to investigate further the issues, and to write it in a thesis entitled An Analysis of Modern Retail Industry Arrangementin the Perspective of Positive Law in Indonesia.

\section{Identification of Problem}

How was the setting of modern retail industry in the perspective of positive law in Indonesia?

\section{B. RESEARCH METHODS}

\section{Types of Study}

According to Peter Mahmud Marzuki, legal research is an activity of know-how in jurisprudence, not just knowabout. As the activity of know-how, legal research carried out to solve a legal issue facing ${ }^{3}$. To solve or to address the issue of the law, it can be done by conducting normative legal research or empirical legal research. This type of research

${ }^{3}$ Peter Mahmud Marzuki, Penelitian Hukum, PT. Kencana, Jakarta, 2010, p. 41 applied to address issues that have been formulated in this study is a normative legal research (normative juridical).

\section{Research Approach}

In relation to the normative research, the writer used the approach of the legislation (statue approach).

\section{Legal Materials}

Legal materials used are $^{4}$ :

a. Primary Legal Materials

Sources of primary legal materials are the source materials that have binding legal force, consisting of:

1) Constitution of the Republic of Indonesia Year 1945;

2) Law No. 12 Year 2011 on the Establishment Legislation;

3) Law No. 7 of 2014 About Trade

4) Law No. 5 of 1999 on Prohibition of Monopolistic Practices and Unfair Competition;

5) Law No. 25 of 2007 on Investment;

6) Presidential Decree No. 112 of 2007 on the Management and Development of Traditional Markets, Shopping Centers and Modern Stores;

\footnotetext{
${ }^{4}$ Soerjono Soekanto and Sri Mamudji, Penelitian Hukum Normatif, PT. RajaGrafindo Persada, Jakarta, 2010, p. 13
} 
7) Government Regulation No. 44 of 1997 concerning the Partnership.

b. Secondary Legal Materials Secondary legal materials are materials that explain the primary legal materials, are as follows:

1) The work of the legal experts related to the title of the study.

2) Legal theories.

3) Official website from the internet.

4) Reading books related to the research title.

5) Research results and other relevant elements of the literature.

Sources of Legal Materials used in the form of notes to load quotations. Searching for legal literature and other information is done by searching through offline (books) and online (internet).

\section{Legal Material Research \\ Procedure}

The procedure used is in the form of a documentation study, namely the guidelines used in the form of notes to load quotations. Searching for legal literature and other information is done by searching through offline(books) and online (internet). Offline library material from can be obtained from private collections and libraries in the form of books, legal journals, articles, newspapers and others, while online library materials can be obtained by using internet access.

\section{Legal Material Analysis}

The analysis used in this study is qualitative juridical analysis. This analysis examines the contents of the rule of law governing the modern retail industry. After being analyzed, legal material is then described in the form of statements and uses deductive-inductive thinking and vice versa for further systematically arranged, so that this analysis will answer the problems raised in the study.

\section{RESULTS AND DISCUSSION}

1. Implementation of the Regulation of the Modern Retail Industry in the Perpective of Positive Law in Indonesia

If we talk about constitutional economy, we are talking about an economy based on constitutional legal norms that are absolute and must not be violated by economic policy makers who are operational in 
nature. ${ }^{5}$ Indonesia, which is a rule of law, has a goal to realize public welfare and social justice for all people. This is as mandated in the opening of the 1945 Constitution of the Republic of Indonesia. This objective shows that Indonesia is a welfare state. In accordance with the understanding of the welfare state that justifies the state to interfere in all areas of life in order to ensure the welfare of its citizens, the country is no longer just a night watchman (nachtwakerstaat) who is only in charge of maintaining order and security. ${ }^{6}$ Therefore, the country represented by the government has a responsibility to be able to realize prosperity for the people, one of which is the economic activity stipulated in the legislation.

The realization of a welfare state must begin with the enforcement of the rule of law (supremacy of law)

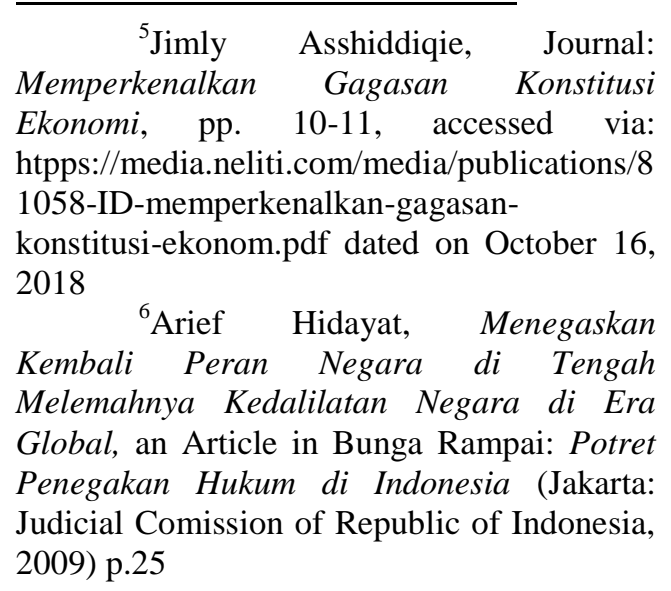

which means positioning the law as commander in the administration of the state, therefore, the government in this case has the responsibility to prepare regulations that can provide justice, certainty and benefit to the people, including regulations regarding the modern retail industry. However, in practice, the concept is not reflected in several laws and regulations governing the modern retail industry. Like the substance of the regulation in Law Number 7 of 2014 concerning Trade which is based on the theory of development law, placing the law as a "guide" in carrying out economic activities does not provide optimal results, both in terms of justice, certainty and benefit, given the regulation this does not regulate clearly and in detail about the activities of the modern retail industry. Indeed, basically, for further regulation, the Act should have implementing rules. In the provisions of Article 121 of Law Number 7 of 2014 concerning Trade, the implementing regulations are no longer than two years from the promulgation of the law. However, in practice until now the implementing 
regulations in question have yet to be implemented.

Then, speaking of economic activities, competition among business actors is definitely one of the important elements that cannot be separated. Competition is essentially needed in business activities, this is in line with what is meant by the theory of competition, where competition is needed to improve the innovative and creative attitude of business actors. The talk about the relation between Law Number 5 Year 1999 concerning Prohibition of Monopolistic Practices and Unfair Business Competition with the activities of the modern retail industry can be seen in terms of the regulation regarding the hours of modern retail management stipulated in Article 7 of Presidential Regulation Number 112 of 2007 concerning Arrangement and Guidance Traditional Markets, Shopping Centers and Modern Shops. In this provision, it is stated that modern retailers are not allowed to open stores for up to 24 hours for hypermarkets, department stores, supermarkets or minimarkets. However, in practice, as happened in several regions, there are still modern retailers that open outlets for up to 24 hours, which is contrary to the applicable provisions. This condition also shows that unhealthy business competition has taken place, what is meant by unhealthy business competition is competition between business actors in carrying out production activities and or marketing of goods and or services that are carried out in an dishonest manner or against the law or hampering business competition. $^{7}$

As explained earlier, that the rise of the modern retail industry in Indonesia is inseparable from the face of growing trade liberalization, in this case the industrial business actors do not only come from domestic businesses but also foreign businessmen who invest or invest in Indonesia. The Indonesian government itself provides convenience in the field of investment, one of which is by providing a National Information Service and Investment Licensing

\footnotetext{
${ }^{7}$ Provisions of Article 1 Number 6 of Act Number 5 of 1999 concerning Prohibition of Monopolistic Practices and Unfair Business Competition Lemonial State of the Republic of Indonesia Number 33 of 1999, Supplement to the State Gazette of the Republic of Indonesia Number 3817
} 
System (SPIPISE) in which investors can easily submit applications for investment licenses, and use this portal to obtain complete information about investment in general. ${ }^{8}$ However, looking at Law No. 25 of 2007 concerning Investment (UUPM), the actual provisions in it constitute the total adoption of the provisions contained in the World Trade Organization (WTO) agreement, where the rules tend to be liberal and contrary to the principle the Indonesian economy is regulated in the provisions of Article 33 of the 1945 Constitution of the Republic of Indonesia. Opposition can be seen in Article 3 paragraph (1) letter $d$ of the Capital Market Law that implies equal treatment of foreign investors and domestic investors. The principle of equality and not differentiating between foreign investors and domestic investors has violated the constitutional mandate regarding the management of the national economy

\footnotetext{
${ }^{8}$ The Investment Coordinating Board, the Online Investment System Relieves Direct Investment Procedures in Indonesia, accessed via: https://www.investindonesia.go.id/id/artikelinvestasi/detail/sistem-inharga-online-mer Light-prosedur-inanaman- direct-in-indonesia on October 28, 2018
}

because it leads to economic liberalization.

Then, in the provisions of Article 12 paragraph (4) the Capital Market Law indicates that the President has the freedom to determine criteria for open business fields so that the potential for personal interests or certain groups arises, especially foreign investors behind the regulation. Talking about the field or type of business that is declared closed and open with the requirements for investment activities, in the retail sector, one of the foreign involvement that can be done that is equal to $67 \%$ in activities "use of a room of at least $400 \mathrm{~m} 2$ and a maximum of 2,000 $\mathrm{m} 2$ and inside mall ", as referred to in Presidential Regulation Number 44 of 2016 concerning List of Closed Business Fields and Open Business Fields known as the Negative Investment List (DNI). However, the rules that limit foreign involvement still have gaps to violate. One way is through the practice of nominees. Nominee practices have a negative impact on the economy, this is due to the tendency to control local resources by 
foreign parties, resulting in the loss of added value to the national economy.

Furthermore,

Government

Regulation Number 44 of 1997 concerning the Partnership also has a role in regulating activities in the modern retail industry. The Ministry of Commerce in 2017 created a partnership program for modern retail and traditional stalls. However, in its implementation according to the Association of Modern Retail Rulers (APRINDO), the partnership program still needs to be adjusted, because not all retail categories are suitable for this partnership scheme. Then, looking at the substance of the regulation, Presidential Regulation No. 112 of 2007 concerning the Arrangement and Development of Traditional Markets, Shopping Centers and Modern Stores has not been able to provide its effectiveness in regulating the activities of the modern retail industry in Indonesia. For example, in its provisions it is stated that the Regional Government has the authority related to licensing and zoning issues which should be regulated in the regional regulations, however, the provision turns out to be ineffective. This is because not all regions have the relevant legal instruments. Based on the theory of certainty, consistency in the implementation of law enforcement in a country is urgently needed so that the main objective of the law is justice and other purposes of legal benefit and certainty. In terms of law enforcement, a regulation can be said to be effective if the law works according to its function. According to Lawrence M. Friedman, there are three elements of the operation of law as a system. These elements are: ${ }^{9}$

a. Substance, the substance element of a legal system is the prevailing legal norms that regulate how law enforcement officials and the public, should behave and behave. Lawrence M. Friedman stated that, "substance is about substantive rules and rules about how institutions should behave".

b. Legal Culture, is how human attitudes toward law, values, thoughts and expectations.

c. Structural, Lawrence M. Friedman stated that, "The structure of a system is its skeletal frame work it is permanent shape, the institutional body of the system". The structure of a system consists of a skeleton

${ }^{9}$ Fitrah Akbar Citrawan, Hukum Persaingan Usaha Penerapan Rule of Reason dalam Penanganan Praktik Kartel, Suluh Media, Yogyakarta, 2017, pp. 40-41 
design, a fixed form, and an agency body of a system.

Based on the explanation above, it can be said that in terms of implementation or enforcement of a rule it must be supported by other elements, not only from the substance of the regulation, but also from the structural and legal culture of the community which also determines the effectiveness of legal rules, including the implementation of regulations modern retail industry in Indonesia so that what is the goal of the law can be achieved, namely justice, certainty and expediency.

\section{Supervision of the Modern}

\section{Retail Industry in Indonesia}

In the process of enforcing the rule of law, in this case the supervisory function is important to ensure that the rules can be implemented properly. The activity of the modern retail industry is an economic activity that has relations with other economic activities, such as business competition and investment. In terms of business competition, the supervisory role as mandated in Law Number 5 Year 199 concerning Prohibition of Monopolistic Practices and Unfair Business Competition is the responsibility of the Business Competition Supervisory Commission (KPPU). Then in terms of investment, the supervisory role is in the Financial Services Authority (OJK) as referred to in Law Number 21 of 2011 concerning the Financial Services Authority. Meanwhile, for the activities of the modern retail industry itself based on the provisions of Article 15 of the Presidential Regulation No. 112 of 2007 concerning the Arrangement and Development of Traditional Markets, the Shopping Centers and Modern Stores which carry out supervisory duties are the government, especially the regional government.

However, in practice as explained earlier, that the local government has not been able to carry out guidance or supervision, this can be seen from the lack of consistency of the government in enforcing the relevant legal rules, both in terms of the availability of regulations and in the government's consistency in implementing regulations already available.

\section{Barriers in Regulating the}

\section{Modern Retail Industry}

a. Juridical Aspect 
Barriers to the modern retail industry regulation of the juridical aspect can be seen on the substance and application of the rules of law relating to the modern retail industry. The substance and application of legal rules from one another should not contradictory to the provisions regarding the hierarchy of the formation of legislation that is subject to the provisions of Article 7 of Law No. 12 of 2011 Concerning the Establishment of Legislation, so that in practice that arises is legal gaps between law in books and law in action.

\section{b. Non Juridical Aspects}

Barriers to arrangement modern retail industry is also affected by the non juridical aspect, including the role of government in the regulation of the modern retail industry is considered to be slow, it can be seen from the revisions proposed by APRINDO related to Presidential Decree No. 112 of 2007 on the Management and Development of Traditional Markets, Shopping Centers and Modern Stores, which the Association has filed a revision in 2015, but until now the process is still stagnant. In addition, government officials' understanding in reading and interpreting a legislation also rated less. Then, the awareness of efforts in conducting its business activities based on the legislation in force also affects the implementation of the modern retail industry settings.

\section{CLOSING}

\section{Conclusion}

Based on the Indonesian positive law, modern retail industry activities are arranged in the relevant regulations. However, implementation of these regulations have not been able to provide fairness, certainty and usefulness as the purpose of a legal rule. The number of regulations governing the activities of the modern retail industry and the absence of legislation specifically regulating this industry in detail resulted in uncertainty so that these regulations are not effective, given the provisions of the legislation with each other are not mutually support or sync with each other as referred to the Law No. 12 of 2011 Concerning the Establishment of Legislation. 


\section{Suggestion}

Looking at the problems in the arrangement of the modern retail industry as have been explained, the writer have suggestions in the form of synchronizing legislation related to the modern retail industry and the consistency of the government in implementing law enforcement so that justice, certainty and benefit can be realized.

\section{REFERENCES}

\section{Books :}

Candra Irawan, Dasar-Dasar Pemikiran Hukum Ekonomi Indonesia, CV.Mandar Maju, Bandung, 2012

Fitrah Akbar Citrawan, Hukum Persaingan Usaha Penerapan Rule Of Reason Dalam Penanganan Praktik Kartel, Suluh Media, Yogyakarta, 2017

Peter Mahmud Marzuki, Penelitian Hukum, PT. Kencana, Jakarta, 2010

Soerjono Soekanto dan Sri Mamudji, Penelitian Hukum Normatif, PT. RajaGrafindo Persada, Jakarta, 2010

Arief Hidayat, Menegaskan Kembali Peran Negara di Tengah MelemahnyaKedalilatan Negara di Era Global, Artikel dalam Bunga Rampai: Potret Penegakan Hukum diIndonesia
(Jakarta: Komisi Yudisial Republik Indonesia, 2009)

Jimly Asshiddiqie, Jurnal: Memperkenalkan Gagasan Konstitusi Ekonomi, hlm.10-11, diakses via: https://media.neliti.com/media/ publications/81058-IDmemperkenalkan-gagasankonstitusi-ekonom.pdf pada tanggal 16 Oktober 2018

\section{Regulation:}

Undang-Undang Dasar Negara Republik Indonesia Tahun 1945, Lembaran Negara Republik Indonesia Tahun 2006 Nomor 14

Undang-undang Nomor 5 Tahun 1999 Tentang Larangan Praktik Monopoli dan Persaingan Usaha Tidak Sehat Lemabaran Negara Republik Indonesia Tahun 1999 Nomor 33, Tambahan Lembaran Negara Republik Indonesia Nomor 3817

\section{Website:}

Badan Koordinasi Penanaman Modal, Sistem Investasi Online Meringankan Prosedur Investasi Langsung di Indonesia, diakses via :https://www.investindonesia.go .id/id/artikelinvestasi/detail/sisteminvestasi-online-meringankanprosedur-investasi-langsung-diindonesia pada tanggal 28 Oktober 2018 